Plant Tissue Cult. \& Biotech. 18(1): 49-56, 2008 (June)

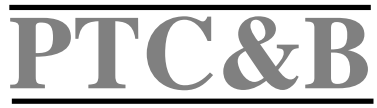

\title{
Rapid Multiplication of Boerhaavia diffusa L. Through In vitro Culture of Shoot tip and Nodal Explants
}

\author{
P. K. Roy \\ Institute of Food and Radiation Biology, Atomic Energy Research Establishment, G.P.O \\ Box No-3787, Dhaka-1000, Bangladesh \\ Key words: Regeneration, Multiple shoots, Boerhaavia diffusa, Explants
}

\begin{abstract}
A rapid in vitro multiple shoot regeneration protocol has been developed in culture of Boerhaavia diffusa. Shoot tips and nodal segments of field grown plants were used as explants and cultured on MS supplemented with different concentrations and combinations of BAP, $\mathrm{Kn}$ and NAA for multiplication of shoots. Maximum multiple shoots were found in MS supplemented with 1.5 $\mathrm{mg} / 1 \mathrm{BAP}$ and $0.5 \mathrm{mg} / 1 \mathrm{NAA}$. After three weeks when they were subcultured in the same medium, the number of shoots per culture increased. Addition of coconut milk in the medium enhanced the number of shoots per culture. For best rooting, well-developed shoots were excised and implanted individually in rooting medium containing half strength of MS fortified with $1.0 \mathrm{mg} / 1$ each of IBA and IAA. Ninety per cent of the cultured shoots produced roots within four weeks of culture. Regenerated plantlets were successfully acclimated and established in soil. About $80 \%$ plantlets survived under field conditions.
\end{abstract}

\section{Introduction}

Mass propagation of plant species through in vitro culture is one of the best and most successful examples of commercial application of plant tissue culture technology. Recently, there has been much progress in this technology for some medicinal plants. Tissue culture in propagation and its importance in conservation of genetic resources and clonal improvement have been described in different books (Barz et al. 1977, Datta and Datta 1985, Kukreja et al. 1989). Boerhaavia diffusa commonly known as punarnava is an important herbaceous medicinal plant. This species is common in Bangladesh, India and other tropical regions of Asia and grows wild in different forests and village groves. The whole plant of $B$. diffusa is a very useful source of the drug punarnava, which is documented in India Pharmacopoeia as a diuretic (Chopra 1969). The active principle contained in the herb is an alkaloid, known as punarnavine. The roots and leaves with flowers have been found to be highly potent (CSIR 1988). In 
ayurvedic medicine, different parts of this plant were reported to have various medicinal properties. It was used in renal ailments as diuretic (Anand 1995) and to treat seminal weakness and blood pressure (Gaitonde et al. 1974). It is also used in the treatment of stomach ache, anemia, cough, cold and a potent antidote for snake and rat bites (Chopra et al. 1956), in the treatment of nephrotic syndrome (Singh and Udupa 1972), hepatitis, gall bladder abnormalities and urinary disorders (Mudgal 1975). The flowers and seeds are used as contraceptive (Chopra et al. 1956).

Pharmacological studies have demonstrated that punarnava possesses punarnavoside, which exhibits a wide range of properties - diuretic (Gaitonde et al. 1974), anti-inflammatory (Bhalla et al. 1968), antifibrinolytic (Jain and Khanna 1989), antibacterial (Olukoya et al. 1993), antihepatotoxic (Mishra 1980), anthelmintic febrifuge, antileprosy, antiasthmatic, antiurethritis (Nadkarni 1976) and antilymphoproliferative activity (Mehrotra et al. 2002). The roots of $B$. diffusa are a rich source of a basic protein or antiviral agent, which is used for inducing systemic resistance in many susceptible crops against commonly occurring viruses (Verma et al. 1979, Awasthi et al.1989). The purified glycoprotein from $B$. diffusa reduced infection and multiplication of tomato yellow leaf curl virus (Awasthi and Rizvi 1999), papaya ring spot virus (Awasthi 2000) and cucumber green mottle mosaic virus (Awasthi et al. 2003). The aqueous crude extract from the dried roots was also found significantly active against a number of viruses - mung bean yellow mosaic virus (Awasthi 2000), bean common mosaic virus (Singh and Awasthi 2002) and water melon mosaic virus (Awasthi 2002).

A large number of publications on the chemistry, pharmacology and several other aspects have been made, but here have been a few reports on in vitro regeneration of Boerhaavia diffusa (Bhansali et al. 1978, Shrivastava and Padhya 1995, Nagarajan et al. 2005). Mass scale collection of this plant from natural habitats is leading to a depletion of this plant species. B. diffusa is propagated by seeds, but the seed viability is poor and has very low germination percentage. Micropropagation method is specifically applicable to species in which clonal propagation is needed (Gamborg and Phillips 1995). In the present paper, an efficient and reproducible clonal propagation system through in vitro culture of B. diffusa has been described.

\section{Materials and Methods}

Shoot tips and nodal segments were collected from the field grown plants of Boerhaavia diffusa. These were washed thoroughly under running tap water for 45 min. Subsequently sterilization was carried out in laminar airflow cabinet under aseptic conditions. Shoot tips and nodal segments were sterilized with $70 \%$ alcohol for 30 seconds followed by $0.1 \% \mathrm{HgCl}_{2}$ accompanied with two drops 
Tween 20 for seven minutes. Rinsing was done five times with sterile distilled water to remove the traces of $\mathrm{HgCl}_{2}$ completely. Before implanting on to the culture media these were cut into small pieces, approximately $3 \mathrm{~cm}$ in length for explants. MS supplemented with different concentrations of BAP (0.5 to 2.5 $\mathrm{mg} / \mathrm{l}), \mathrm{Kn}(0.5$ to $2.5 \mathrm{mg} / \mathrm{l})$ and NAA $(0.25$ to $0.5 \mathrm{mg} / \mathrm{l})$ were used singly or in combination for the induction and development of multiple shoots from cultured explants. All media contained 3\% sucrose and $0.7 \%$ agar with $\mathrm{pH} 5.8$, adjusted before autoclaving. For rooting 3-4 cm long regenerated shoots were excised and cultured on freshly prepared rooting medium containing half strength of MS with different concentrations and combinations of IBA, IAA and NAA. Effect of coconut milk $(\mathrm{CM})$ on shoot multiplication was also determined. The cultures were maintained at $25 \pm 2{ }^{\circ} \mathrm{C}$ under $16 \mathrm{~h}$ photoperiod. In vitro rooted plantlets were taken out from the test tubes and gently washed to free them from medium. Then they were transplanted to small earthen pots containing a mixture of soil and compost $(2: 1)$ and covered with transparent polyethylene lid to maintain high humidity. After ten days polyethylene lid was removed and after two months the plants were planted in the open field.

\section{Results and Discussion}

Different explants were cultured on MS supplemented with different concentrations of BAP, $\mathrm{Kn}$ and NAA alone or in various combinations for multiple shoot regeneration. All explants comprising shoot tips and nodal segments were cultured for direct multiple shoot regeneration. In both the shoot tip and nodal explants, the highest percentage (90) of shoot induction was observed in MS $+1.5 \mathrm{mg} / 1 \mathrm{BAP}+0.5 \mathrm{mg} / 1 \mathrm{NAA}$ (Table 1). In this combination an average of $5 \pm 0.2$ shoots regenerated from shoot tip explants whereas $12 \pm 0.3$ shoots regenerated from nodal explants (Table 1, Figs. 1, 2). The medium containing Kn alone did not form multiple shoots. Nodal explants with two axillary meristems gave better response than shoot tip explants with a single apical meristem. On the medium containing BAP and NAA, both the explant responded well and produced more shoots than the medium containing only cytokinin. Roy et al. (1995) observed similar response in case of medicinal plant Rauvolfia serpentina. More or less similar response was also observed Nagarajan et al. (2005) in B. diffusa and Ahmed et al. (2001) in Holarrhena antidysenterica L. In an attempt to enhance shoot proliferation CM $(5-20 \% \mathrm{v} / \mathrm{v})$ was added to the medium. Addition of $10 \% \mathrm{CM}$ to the medium increased the number of shoots (nodal explants $=15$, shoot tip explants $=8$ ) per culture (Fig. 5). Thus the more effective medium determined for rapid multiplication of shoots with suitable length was MS $+1.5 \mathrm{mg} / 1 \mathrm{BAP}+0.5 \mathrm{mg} / 1 \mathrm{NAA}+10 \% \mathrm{CM}$. Roy et al. (1998) reported that addition of $10 \% \mathrm{CM}$ in the medium increased the number of shoots in Elaeocarpus 
robustus culture. Rahman et al. (1999) also observed similar effects on Emblica officinalis culture.

Table 1. Effect of growth regulators in MS basal medium on shoot proliferation from shoot tip and nodal explants of Boerhaavia diffusa. Data were taken after six weeks of culture.

\begin{tabular}{|c|c|c|c|c|}
\hline \multirow[t]{2}{*}{$\begin{array}{l}\text { Growth regulators } \\
(\mathrm{mg} / \mathrm{l})\end{array}$} & \multicolumn{2}{|c|}{$\begin{array}{l}\% \text { explants showing shoot } \\
\text { regeneration }\end{array}$} & \multicolumn{2}{|c|}{$\begin{array}{l}\text { Average number of } \\
\text { shoots/explant }\end{array}$} \\
\hline & Shoot tip & Nodal segment & Shoot tip & Nodal segment \\
\hline $0.5 \mathrm{BAP}$ & 40 & 45 & $2 \pm 0.2$ & $4 \pm 0.2$ \\
\hline 1.0 BAP & 50 & 50 & $3 \pm 0.3$ & $4 \pm 0.3$ \\
\hline 1.5 BAP & 60 & 60 & $3 \pm 0.2$ & $5 \pm 0.3$ \\
\hline $2.0 \mathrm{BAP}$ & 50 & 55 & $2 \pm 0.2$ & $3 \pm 0.2$ \\
\hline 2.5 BAP & 45 & 48 & $3 \pm 0.4$ & $3 \pm 0.4$ \\
\hline $0.5 \mathrm{Kn}$ & 10 & 10 & - & $3 \pm 0.2$ \\
\hline $1.0 \mathrm{Kn}$ & 20 & 25 & - & $3 \pm 0.4$ \\
\hline $1.5 \mathrm{Kn}$ & 30 & 30 & $2 \pm 0.3$ & $4 \pm 0.2$ \\
\hline $2.0 \mathrm{Kn}$ & 25 & 28 & - & - \\
\hline $2.5 \mathrm{Kn}$ & 20 & 25 & - & - \\
\hline $0.5 \mathrm{BAP}+0.25 \mathrm{NAA}$ & 50 & 50 & $3 \pm 0.5$ & $5 \pm 0.3$ \\
\hline $1.0 \mathrm{BAP}+0.25 \mathrm{NAA}$ & 60 & 65 & $4 \pm 0.3$ & $6 \pm 0.2$ \\
\hline $1.5 \mathrm{BAP}+0.25 \mathrm{NAA}$ & 70 & 75 & $4 \pm 0.4$ & $7 \pm 0.3$ \\
\hline $2.0 \mathrm{BAP}+0.25 \mathrm{NAA}$ & 68 & 70 & $2 \pm 0.2$ & $5 \pm 0.5$ \\
\hline $2.5 \mathrm{BAP}+0.25 \mathrm{NAA}$ & 60 & 60 & $2 \pm 0.2$ & $4 \pm 0.2$ \\
\hline $0.5 \mathrm{BAP}+0.5 \mathrm{NAA}$ & 45 & 50 & $3 \pm 0.4$ & $6 \pm 0.3$ \\
\hline $1.0 \mathrm{BAP}+0.5 \mathrm{NAA}$ & 70 & 75 & $4 \pm 0.3$ & $8 \pm 0.2$ \\
\hline $1.5 \mathrm{BAP}+0.5 \mathrm{NAA}$ & 90 & 90 & $5 \pm 0.2$ & $12 \pm 0.3$ \\
\hline $2.0 \mathrm{BAP}+0.5 \mathrm{NAA}$ & 70 & 70 & $3 \pm 0.3$ & $6 \pm 0.2$ \\
\hline $2.5 \mathrm{BAP}+0.5 \mathrm{NAA}$ & 60 & 65 & $3 \pm 0.2$ & $4 \pm 0.8$ \\
\hline $0.5 \mathrm{BAP}+0.5 \mathrm{Kn}$ & 50 & 55 & $2 \pm 0.3$ & $4 \pm 0.3$ \\
\hline $1.0 \mathrm{BAP}+0.5 \mathrm{Kn}$ & 50 & 50 & $3 \pm 0.3$ & $5 \pm 0.2$ \\
\hline $1.5 \mathrm{BAP}+0.5 \mathrm{Kn}$ & 45 & 50 & $3 \pm 0.2$ & $5 \pm 0.3$ \\
\hline $2.0 \mathrm{BAP}+0.5 \mathrm{Kn}$ & 40 & 45 & $2 \pm 0.4$ & $4 \pm 0.3$ \\
\hline $2.5 \mathrm{BAP}+0.5 \mathrm{Kn}$ & 40 & 40 & - & $3 \pm 0.2$ \\
\hline
\end{tabular}

'-' indicates single shoot growth.

For root induction, well-developed in vitro shoots were excised and cultured on root induction medium. Different concentrations of IBA, IAA and NAA were used in half strength of MS for root induction. The best response was observed when $1.0 \mathrm{mg} / 1$ each of IBA and IAA were added to half strength of MS (Table 2). In this combination, it was observed that $90 \%$ shoots rooted within 30 days of 
culture and each microcutting produced 30 - 32 roots (Table 2, Fig. 3). A combination of two auxins was more effective for root induction in Syzygium cuminii (Yadav et al. 1990). For hardening and plant establishment under the natural conditions, the well rooted plantlets were transferred to small earthen pots containing a mixture of soil and compost $(2: 1)$ (Fig. 4). During hardening $80 \%$ plantlets survived and these were subsequently transferred to field. The present work demonstrates a simple and successful protocol for rapid clonal propagation of Boerhaavia diffusa through in vitro culture.
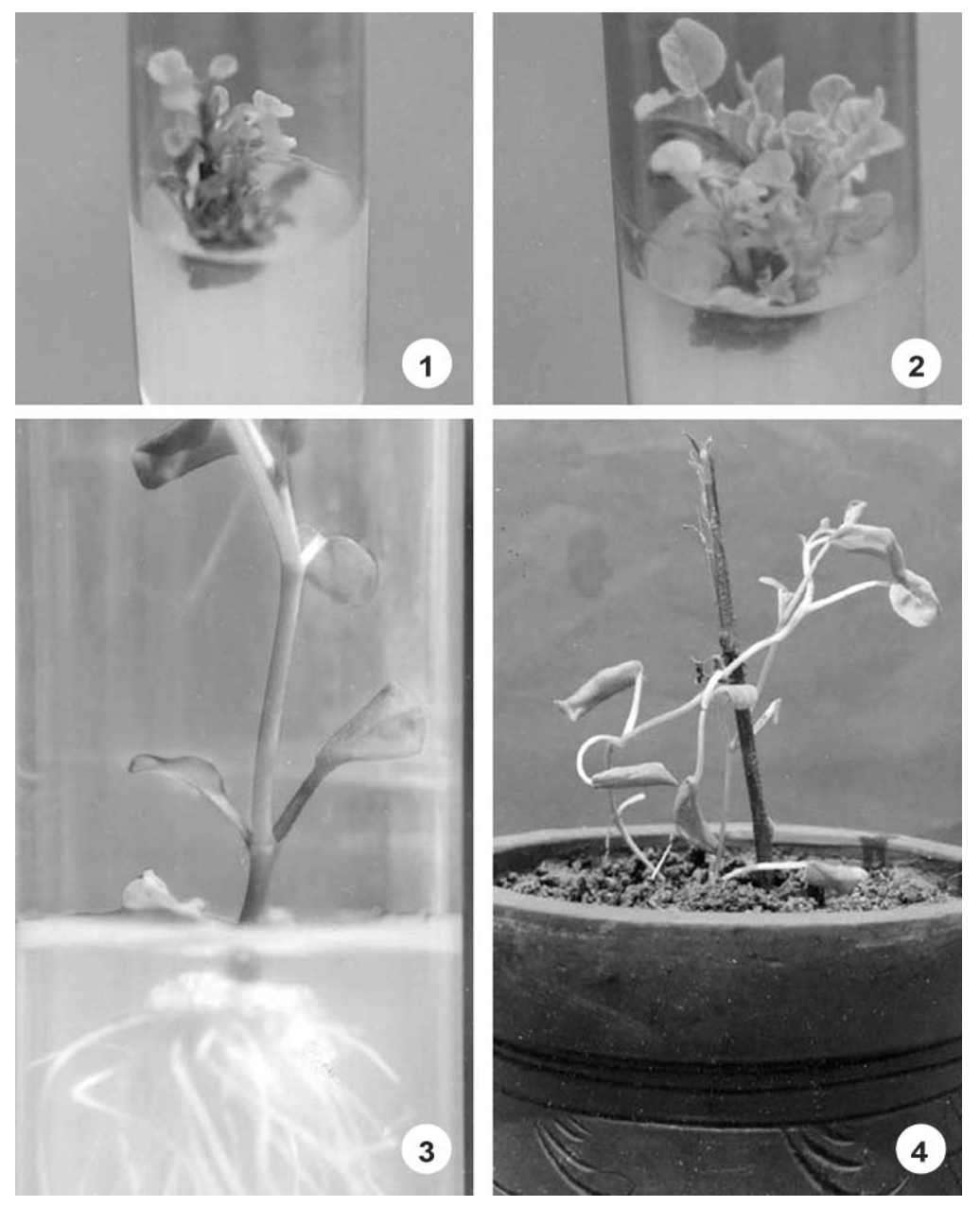

Figs. 1-4. In vitro regeneration of Boerhaavia diffusa. 1. Multiple shoot formation from shoot tip on MS $+1.5 \mathrm{mg} / 1 \mathrm{BAP}+0.5 \mathrm{mg} / 1 \mathrm{NAA}$. 2. Multiple shoot regeneration from nodal segment on MS + $1.5 \mathrm{mg} / 1 \mathrm{BAP}+0.5 \mathrm{mg} / 1 \mathrm{NAA}$. 3. In vitro root induction on half strength of MS supplemented with $1.0 \mathrm{mg} / \mathrm{l}$ each of IBA and IAA. 4 . Regenerated plantlet in earthen pot 
Table 2. Effect of auxins in half strength of MS on root formation from regenerated shoots of B. diffusa. Data were taken after 30 days of culture.

\begin{tabular}{lccc}
\hline $\begin{array}{c}\text { Growth regulators } \\
(\mathrm{mg} / \mathrm{l})\end{array}$ & $\begin{array}{c}\text { Rooted shoot } \\
(\%)\end{array}$ & $\begin{array}{c}\text { Number of } \\
\text { roots/culture }\end{array}$ & $\begin{array}{c}\text { Average root } \\
\text { length }(\mathrm{cm})\end{array}$ \\
\hline 0.5 IBA & 50 & $18-20$ & $6 \pm 0.2$ \\
1.0 IBA & 70 & $20-24$ & $8 \pm 0.3$ \\
1.5 IBA & 65 & $15-18$ & $5 \pm 0.2$ \\
2.0 IBA & 60 & $12-14$ & $4 \pm 0.2$ \\
0.5 IAA & - & - & - \\
1.0 IAA & 30 & $7-9$ & $4 \pm 0.4$ \\
1.5 IAA & 10 & $6-8$ & $5 \pm 0.3$ \\
2.0 IAA & - & $6-8$ & $6 \pm 0.2$ \\
0.5 IBA + 0.5 IAA & 60 & $18-20$ & $8 \pm 0.2$ \\
1.0 IBA + 0.5 IAA & 75 & $22-24$ & $7 \pm 0.3$ \\
1.5 IBA + 0.5 IAA & 70 & $20-22$ & $6 \pm 0.2$ \\
2.0 IBA + 0.5 IAA & 50 & $16-18$ & $7 \pm 0.4$ \\
0.5 IBA + 1.0 IAA & 65 & $24-26$ & $8 \pm 0.3$ \\
1.0 IBA + 1.0 IAA & 90 & $30-32$ & $8 \pm 0.2$ \\
1.5 IBA + 1.0 IAA & 70 & $20-22$ & $4 \pm 0.2$ \\
2.0 IBA + 1.0 IAA & 60 & $17-19$ & $4 \pm 0.3$ \\
0.5 IBA + 0.5 NAA & 78 & $18-20$ & $5 \pm 0.2$ \\
1.0 IBA + 0.5 NAA & 80 & $25-27$ & $7 \pm 0.3$ \\
1.5 IBA + 0.5 NAA & 68 & $18-22$ & $6 \pm 0.2$ \\
2.0 IBA + 0.5 NAA & 50 & $15-18$ & $5 \pm 0.2$ \\
1.0 IBA + 0.5 IAA + 0.5 NAA & 55 & $20-22$ & $7 \pm 0.4$ \\
1.0 IBA + 1.0 IAA + 0.5 NAA & 70 & $24-26$ & $5 \pm 0.3$ \\
1.5 IBA + 1.0 IAA + 1.0 NAA & 58 & $16-18$ & $4 \pm 0.2$ \\
\hline
\end{tabular}

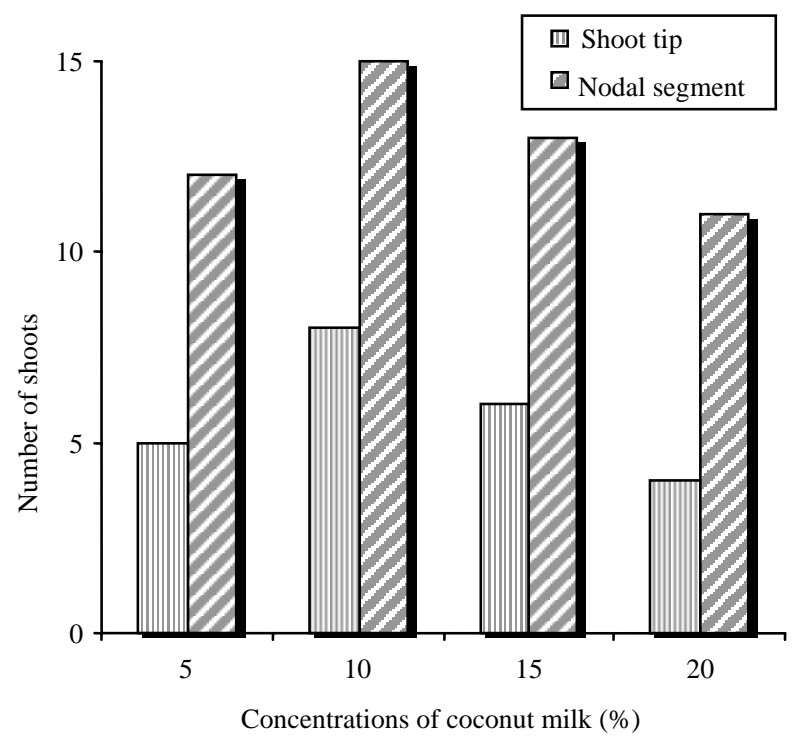


Fig 5. Effect of different combinations of coconut milk (5-20\% v/v) along with MS +1.5 $\mathrm{mg} / 1 \mathrm{BAP}+0.5 \mathrm{mg} / 1 \mathrm{NAA}$ on number of shoot development.

\section{References}

Ahmed G, Roy PK and Mamun ANK (2001). High frequency shoot regeneration from nodal and shoot tip explants in Holarrhena antidysenterica L. Indian Journal of Experimental Biology 39 : 1322-1324.

Anand RK (1995). Biodiversity and tribal association of Boerhaavia diffusa in India-Nepal Himalayan Terai Region. Flora \& Fauna 2: 167-170.

Awasthi LP (2000). Protection of crop plants against virus diseases through root extract of Boerhaavia diffusa. Indian Phytopathology 54(4): 508-509.

Awasthi LP (2002). Prevention of infection and multiplication of water melon mosaic virus disease in water melon. In: Abstracts, Plant Health for Food Security, Asian Congress of Mycology and Plant Pathology, 1-4 Oct 2002, University of Mysore, Mysore, Karnatak, India. p. 416.

Awasthi LP, Kluge S and Verma HN (1989). Characteristics of antiviral agents induced by Boerhaavia diffusa glycoprotein in host plants. Indian Journal of Virology. 3:156-169.

Awasthi LP, Kumar P and Singh RV (2003). Effect of Boerhaavia diffusa inhibitor on the infection and multiplication of cucumber green mottle mosaic virus in musk melon plants. Indian Phytopathology 56(3): 362.

Awasthi LP and Rizvi SMA (1999). Effect of Boerhaavia diffusa glycoprotein on the transmission of tomato yellow leaf curl virus by Bemisa tabaci Gen. In: abstracts, National Symposium on Vectors of Plant Diseases, 11-13 Nov 1999, Narendra Dev University of Agriculture and Technology, Kumarganj, Faizabad, Uttar Pradesh, India. p. 56.

Barz W, Reinhard E and Zenk MH (1977). Plant tissue culture and its biotechnological application. Springer Verlag, Berlin, New York, 27 - 43.

Bhalla TN, Gupta MB, Sheth PK and Bhargava KP (1968). Antiinflammatory activity of Boerhaavia diffusa. Indian Journal of Physiology and Pharmacology 12: 37-40.

Bhansali RR, Kumar A and Arya HC (1978). In vitro induction of adventitious shoots on stem explants of Boerhaavia diffusa. Current Science 47: 551-552.

Chopra GL (1969). Angiosperms. Systematics and Life Cycle. S. Nagin \& Co., Jalandhar, Punjab, India. pp. 361-365.

Chopra RN, Nayar SL and Chopra IC (1956). Glossary of Indian Medicinal Plants. Council of Scientific and Industrial Research (CSIR), New Delhi, India p. 39.

CSIR (1988) The welth of India: Raw Materials Vol. VII B. CSIR, New Delhi, India. p.174.

Datta PC and Datta SC (1985). Applied biotechnology on medicinal, aromatic and timber plants. Calcutta University, Calcutta, India.

Gamborg OL and Phillips GC (1995). Laboratory facilities, operation and management. In : Gamborg OL and Phillips GC (ed.) Fundamental methods of plant cell, tissue and organ culture. Springer, Berlin, New York, pp. 3-20

Gaitonde BB, Kulkarni HJ and Nabar SD (1974). Diuretic activity of punarnava (Boerhaavia diffusa). Bulletins of the Haffkine Institute (Bmbay, India) 2: 24.

Jain GK and Khanna NM (1989). Punarnavoside: A new antifibrinolytic agent from Boerhaavia diffusa L. Indian Journal of Chemistry 28(B): 163-166. 
Kukreja AK, Mathur AK, Ahuja PS and Thakur RS (1989). Tissue culture and biotechnology of medicinal and aromatic plants. ICSIR, Lucknow.

Mehrotra S, Singh VK, Agarwal SS, Maurya R and Srimal RC (2002). Antilymphoproliferative activity of ethanolic extract of Boerhaavia diffusa roots. Experimental and Molecular Pathology 72(3): 236-242.

Mishra JP (1980). Studies on the effect of indigenous drug Boerhaavia diffusa on kidney regeneration. Indian Journal of Pharmacy 12: 59-63.

Mudgal V (1975). Studies on medicinal properties of Convolvulus pluricaulis and Boerhaavia diffusa. Planta Medica 28: 62-68.

Nadkarni AK (1976). Indian Meteria Medica. Vol. I. A.K. Nadkarni, Popular Prakashan Pvt. Ltd., Bombay, Maharashtra, India pp. 203-205.

Nagarajan SM, Suresh T, Rajasekaran S, Kannan TMS and Kulothungan S (2005). In vitro micropropagation of Boerhaavia diffusa L. Geobios-Jodhpur 32: 169-172.

Olukoya DK,Tdika N and Odugbemi T (1993). Antibacterial activity of some medicinal plants from Nigeria. Journal of Ethnopharmacology 39: 69-72.

Rahman MM, Roy PK, Mannan MA and Roy SK (1999). Clonal propagation of Emblica officinalis through in vitro culture. Plant Tissue Cult. 9(1) : 17-23.

Roy SK, Roy PK, Rahman M and Hossain T (1995). Clonal propagation of Rauvolfia serpentina through in vitro culture. Acta Hort. 390 : 141-146.

Roy SK, Islam MS and Hadiuzzaman S (1998). Micropropagation of Elaeocarpus robustus Roxb. Plant Cell Reports. 17: 810 - 813

Shrivastava N and Padhya MA (1995). 'Punarnavine' profile in the regenerated roots of Boerhaavia diffusa from leaf segments. Curr. Sci. 68: 653-656.

Singh RH and Udupa KN (1972). Studies on the Indian indigenous drug punarnava (Boerhaavia diffusa). Part IV: Preliminary controlled clinical trial in nephrotic syndrome. Journal of Research in Indian Medicine 7: 28-33.

Singh S and Awasthi LP (2002). Prevention of infection and spread of bean common mosaic virus disease of mung bean through botanicals. Indian Journal of Mycology and Plant Pathology 32(1) : 141-145.

Verma HN, Awasthi LP and Saxena KC (1979). Isolation of virus inhibitor from the root extract of Boerhaavia diffusa inducing systemic resistance in plants. Can. J. Bot. 57: 1214- 1218.

Yadav V, Madan L and Jaiswal VS (1990). In vitro micropropagation of the tropical fruit tree syzygium cuminii L. Plant Cell Tissue and Organ Cult. 21 : 87 - 92. 